\title{
Corrigendum: Reimagining New Socio-Technical Economics Through the Application of Distributed Ledger Technologies
}

\author{
Sarah Manski ${ }^{1 *}$ and Michel Bauwens ${ }^{2 *}$ \\ ${ }^{1}$ Department of Global Studies, University of California, Santa Barbara, Santa Barbara, CA, United States, ${ }^{2}$ P2P Foundation, \\ Amsterdam, Netherlands
}

Keywords: blockchain, distributed ledger technology, cosmo-local production, cooperatives, sovereignty, distributed value accounting

\section{A Corrigendum on}

Reimagining New Socio-Technical Economics Through the Application of Distributed Ledger Technologies

by Manski, S., and Bauwens, M. (2020). Front. Blockchain 2:29. doi: 10.3389/fbloc.2019.00029

In the original article, there was a mistake in Figure 3 as published. We wrote "Alex Pazaites" instead of "Alex Pazaitis." In addition, Bauwens, M., and Pazaitis, A. (2019) and Pazaitis, A. (2020) were not cited. They have been added in the following places:

The legend of Figure 1.

OPEN ACCESS

Edited and reviewed by: Jane Thomason, University of Queensland, Australia

*Correspondence: Sarah Manski

smanski@ucsb.edu

Michel Bauwens michelsub2004@gmail.com

Specialty section: This article was submitted to Blockchain for Good a section of the journal Frontiers in Blockchain

Received: 27 January 2020 Accepted: 03 March 2020 Published: 07 April 2020

Citation:

Manski S and Bauwens M (2020) Corrigendum: Reimagining New Socio-Technical Economics Through the Application of Distributed Ledger Technologies. Front. Blockchain 3:14.

doi: 10.3389/fbloc. 2020.00014
Figure 1. Generative vs. extractive economies: four competing socio-technological value systems (used with permission. Graphic by Michel Bauwens, published in "P2P Accounting for Planetary Survival," P2P Foundation, upcoming 2019). This framework was first introduced in Kostakis and Bauwens (2014) and was re-worked and published in the form used in this article in Bauwens and Pazaitis (2019, p. 35).

Part 5: New Forms of Value Accounting for Post-Capitalist Production, paragraph 2.

"Resources-Events-Agents (REA) is an accounting system for networked cooperation and shared supply chains. Resources-Events-Agents (REA) is a radical innovation for accounting which hitherto has been based on double entry bookkeeping, which takes an individualistic or corporate point of view, aimed at increasing the capital base of a commercial entity. REA on the contrary offers an "independent" eco-systemic view of the flows between participants in an ecosystem and evolved in the context of integrated supply chains. Metaphorically, this abandonment of double entry is symptomatic in our opinion from a shift from a capitalist point of view, based on competing corporations or nations, to a cooperative point of view, based on networks of cooperation in joint ecosystems. REA is a model for an accounting system re-engineered for the information age. It was originally presented by McCarthy (1982) as a generalized framework designed to cover certain needs for information management that traditional accounting could not adequately address. The main motivation behind the development of REA have been the limitations of doubleentry bookkeeping in providing the necessary information to facilitate decision making in business entities (Bauwens and Pazaitis, 2019; Pazaitis, 2020)."

Finally, "Resource-Events-Actions" was changed to "Resource-Events-Agents". This has been corrected in Part 3: A Survey of Post-Blockchain Ledgers for Shared Supply Chains, paragraph 11:

"Similarly, flow accounting, takes the form of Resource-Events-Agents accounting 6 . These forms of value accounting do not use double entry ledgers but seek to describe how every transaction 
takes place in a multi-dimensional ecosystem. It shows, "where in the flow," the transaction occurs. Additionally, thermodynamic accounting is the ability to place oneself, and have direct access, to the vision of the real flows of matter and energy that one is using, without financializing these flows. The Reporting 3.0 framework is, along with MUSIASEM one of the prime examples of this approach. Such knowledge can

\section{REFERENCES}

Bauwens, M., and Pazaitis, A. (2019). P2P Accounting for Planetary Survival. Supported by the Guerilla Foundation and Shoepflin Foundation. Available online at: https://commonstransition.org/p2p-accounting-for-planetarysurvival/

McCarthy, W. E. (1982). The REA accounting model: a generalized framework for accounting systems in a shared data environment. Account. Rev. $554-578$. also be embedded in programmable currencies, such as the Fishcoin, a form of money that represents the amount of fish that can be taken without endangering the reproduction cycles of such fish."

The authors apologize for these errors and state that this does not change the scientific conclusions of the article in any way. The original article has been updated.

Pazaitis, A. (2020). Breaking the chains of open innovation: post-Blockchain and the case of Sensorica. Information 11:104. doi: 10.3390/info11020104

Copyright (C) 2020 Manski and Bauwens. This is an open-access article distributed under the terms of the Creative Commons Attribution License (CC BY). The use, distribution or reproduction in other forums is permitted, provided the original author(s) and the copyright owner(s) are credited and that the original publication in this journal is cited, in accordance with accepted academic practice. No use, distribution or reproduction is permitted which does not comply with these terms. 